\title{
Palate Squamous Cell Carcinoma
}

National Cancer Institute

\section{Source}

National Cancer Institute. Palate Squamous Cell Carcinoma. NCI Thesaurus. Code C4649.

A squamous cell carcinoma that arises from the hard or soft palate. 